\title{
Public Sociology in Print: A \\ Comparative Analysis of Book Publishing in Three Social Science DISCIPLINES
}

\author{
Alex Mochnacki \\ AARON SEgAert \\ Neil McLaughlin
}

\begin{abstract}
Much discussion surrounding Burawoy's (2004; 2005) argument for public sociology has focused on concerns about the model's normative and political implications while failing to empirically analyze current practices of public academic work. The debate thus risks devolving into competing rhetorical claims about what public sociology should be. We offer a preliminary comparative analysis of one type of public academic work - the writing of books by sociologists, political scientists, and economists in Canada. In the hope of encouraging more empirical research on the current status of public academic work in Canada, books are put into one of six categories determined on the basis of 1) the publisher's characteristics; 2) the book's intended audience; and 3) the book's intended intellectual/political purpose. We find that sociology lags behind political science in producing books intended for a public audience; however, other evidence suggests Canadian sociologists are attempting to open a public dialogue in a more "organic" way through small presses. Questions are raised about the status and rewards structure of professional sociology in Canada and how it influences public academic work.
\end{abstract}

Key words: books; publishing; Canadian sociology; economics and political science; public sociology

Résumé. Les discussions à propos des arguments de Burawoy sur la sociologie publique se concentrent principalement autour des implications normative et politique du modèle. Mais ces discussions omettent de tester empiriquement les travaux académiques publics contemporains. Il existe donc un risque que le débat s'égare en discussions rhétoriques autour de ce que la sociologie publique devrait être. Nous proposons une analyse préliminaire d'un type de travail académique public, soit la production de livres par des sociologues, politologues et économistes au Canada. Dans l'espoir d'inciter les recherches empiriques sur le statut actuel des travaux académiques publics au Canada, nous avons classé les 
ouvrages en six catégories sur les bases suivantes 1) les caractéristiques institutionnelles de l'éditeur, 2) le public visé par les livres, 3) l'usage intellectuel et politique attendu pour le livre. Les résultats de nos recherches montrent que la sociologie accuse un retard face à la science politique quant à la production de livres commerciaux grand public. Cependant, d'autres preuves suggèrent que les sociologues canadiens tentent d'ouvrir un dialogue public d'une manière plus « organique » au travers de la publication chez de petits éditeurs. Nous nous posons des questions quant au statut et à la structure de valorisation professionnelle de la sociologie au Canada et à leur influence sur les travaux académiques publics. Mots-clés: les livres; publication; sociologie canadien; sciences économiques et science politique; sociologie publique

M ichael Burawoy's (2004; 2005) argument for a revitalized public sociology stands as both a normative vision for and a theoretical diagnosis of the discipline. However, most of the discussion that has emerged in its wake has engaged the normative issues while failing to empirically ground the debate in sound social science knowledge concerning the practical dynamics of public academic work more generally (McLaughlin, Kowalchuk and Turcotte 2005: McLaughlin and Turcotte 2007). Serious efforts at assessing the usefulness of Burawoy's model, the opportunities and risks his vision of public sociology offers for the discipline in Canada, require sustained theoretical and empirical research. While a truly reflexive sociology must be willing to rigorously analyze the discipline of sociology itself (Bourdieu and Wacquant 1992; Gouldner 1970; McLaughlin 2005), we fear that the "excitement" of a debate on public sociology could easily devolve into polemics rooted in professional self-interest and pre-existing political commitments. More empirical data on the state of public sociology (and public intellectualism, more generally) is needed if such a situation is to be avoided. In this paper, we report the findings of a comparative analysis of book publication as a measure or operationalization of public academic work by scholars from three disciplines: sociology, political science, and economics.

Burawoy presents a four-category model of sociological labour divided along the axes of audience (internal and external) and knowledge types (instrumental and reflexive). Traditional scholarly research is the work of professional sociology, producing instrumental knowledge for academic audiences. Professional sociology concerns itself with methodological, theoretical, or empirical puzzles arising out of its own research program. Critical sociology is likewise directed towards an academic audience, but its knowledge is reflexive, engaging the moral and normative aspects of the discipline and the epistemological assumptions of existing research programs. Policy sociology generates instrumental knowledge that addresses problems defined by clients outside the 
academy. Finally, public sociology produces reflexive knowledge about issues significant to a particular public. According to Burawoy, the trajectory of one's sociological career may lead into any or all of these quadrants at various times, with the work done in each quadrant serving to contrast and complement the work within the others. The image conveyed is of a discipline whose vitality rests on the balance of these four diverse facets, and it is this image that has inspired the ensuing debate.

McLaughlin, Kowalchuk and Turcotte (2005) argue that the debate regarding public sociology should be more empirically grounded. They identify two major problems with Burawoy's model of public sociology. First, Burawoy's key concepts - critical, reflexive, and public - are ambiguous and open to multiple competing interpretations ${ }^{1}$. Second, his model does not put enough emphasis on the role institutional context plays in sustaining the four types of sociological work, something that is emphasized in Burawoy's discussion but disappears in the knowledge versus audience table.

Putting these larger issues in the background for the moment, we would like to move the debate in the direction of analyzing different genres of "doing" public sociology. Specifically, we offer a theoretically informed empirical analysis of book publishing in three social science disciplines in Canada. This complements an analysis of op-ed writing offered elsewhere in this special issue (Kowalchuk and McLaughlin, this issue). While the debate over the normative issue of whether sociology should be more public or not is important, it runs the risk of devolving into a purely rhetorical struggle over who is more reflexive, public or critical. This gives us little useful information about what sociologists actually $d o$ during their professional working days. It is our view that we need a reliable measure of the public intellectual activity of Canadian sociologists; that is, we need an empirical sense of their actual practices of public engagement rather than their professed values as expressed in surveys or public relations-oriented mission statements. To that end, we have put aside the thorny question of how to operationalize the contested terms at the core of Burawoy's model - critical, reflexive, and public - in order to concentrate on one aspect or measure of Canadian public intellectual activity: the publication of books by Canadian sociologists, political scientists, and economists.

Drawing on the field theory of Pierre Bourdieu, Burawoy reminds us that sociology is a field of power where cultural capital is distributed unequally and the "rules of the game" shape intellectual labour and the form that it takes. These dynamics undoubtedly operate in sociology, but

1. For instance, Lynch (2000) provides a useful overview of the various uses of the term "reflexivity" in the social sciences. 
we want to draw on both Bourdieu and the comparative organizational sociology of disciplines pioneered by Richard Whitley (1984) to ask a range of empirical questions that put sociology into a comparative perspective. Although Bourdieu is widely recognized as a critical and even public sociologist within the Canadian scholarly community, ${ }^{2}$ the implications of his sociology of intellectuals and academics are sometimes not fully appreciated (but see Curtis and Weir 2002). From an orthodox Bourdieuan perspective, scholars who produce written work that resonates among journalists and/or the general public through media coverage and commercial publications are often suspected of bypassing traditional peer-review standards in an attempt to gain symbolic capital outside of the academic field. Whitley, the most important scholar in the study of comparative "intellectual and social organization of the sciences," likewise has raised concerns about how scholarship addressed to lay audiences undermines the reputational control of scientific work, which he sees as central to producing rigorous science (Whitley 1984).

Who writes to the public in Canadian sociology today, and what combination of outlets and genres (e.g., commercial or popular books, public lectures, television appearances, op-eds in newspapers) do public sociologists use? What relative status position do public sociologists in Canada hold within their own discipline, and how might sociologists rank as public intellectuals compared to scholars from other disciplines? Do public sociologists come from elite research universities or more teaching-focused undergraduate universities, and how does this differ by discipline? How do gender, age, and research specialization shape public academic activities?

We intend to create a starting point for thinking about these kinds of questions by offering a preliminary study that compares book writing among Canadian sociologists, political scientists and economists. Book publishing, of course, is only one way that academics can speak to the public; they also reach lay publics through their teaching, writing op-eds, public speaking, by writing essays in non-academic publications, etc. There is an existing literature that looks at the relationship of book versus article publishing in and between various disciplines, and a growing literature on book publishing as a cultural industry (Clemens et al. 1995; Coser et al. 1982; Hiller and Langlois 2001; Nock 1992; 2001; Wolfe 1990). However, there is no research that focuses specifically on the dynamics of academics who reach the public through books in a comparative context. We hope our modest study will provide empirical material to help stimulate debate on this aspect of public sociology in Canada.

2. Swartz (2000) provides an interesting analysis of Bourdieu's transformation into a public intellectual. 
We should note the inherent differences between sociology, political science, and economics. Economics, much more than sociology or political science, has adopted a research model closer to that of the natural sciences. It emphasizes peer-reviewed articles rather than books (Clemens et al. 1995; Wolfe 1990) and strongly emphasizes highly technical mathematical and quantitative research which is well suited to the journal article format. Political science on the other hand deals with a subject - politics - that is of natural interest to the public in a democracy, and since the general public has limited exposure to academic journals, books are a more practical format for reaching that audience. Sociology is differentiated from economics and political science in that its subject matter is broader, more inclusive, and more synthetic. As well, it is notorious for its broad range of "competing" methods and theoretical perspectives. With this background in place, we turn to a discussion of the methods we used.

\section{Theorizing and Studying Public Sociology in Comparative Perspective}

\section{Data and Methods}

We constructed six analytical categories of books written by academics that are targeted at divergent audiences and intended to achieve somewhat different intellectual ends. Each of the six represents the product of a different type of academic labour. The six analytical categories of books we consider are: 1) textbooks; 2) university press monographs; 3 ) commercial academic press monographs; 4) commercial popular press books; 5) small press (agenda) books; and 6) small press (nonagenda) books (see Appendix A for a detailed list of presses and how we classified them). Figure 1 details our criteria and typology in summary form. We discuss below both the utility and the potential weaknesses of our typology. Using these six analytical categories, we then compare the book publishing practices of academics in sociology, political science, and economics.

While we include textbooks in our typology, we focus the bulk of our attention on the other types of books published by Canadian sociologists, political scientists, and economists. Although the production of disciplinary textbooks is essential to the reproduction of scholarly knowledge, textbook writing is conventionally ascribed a low status within academic professions. Textbooks service the education of undergraduate students and, in contrast to other professional works, are not directed towards a community of academic peers. Textbooks do not produce new scholarly knowledge but rather convey and summarize existing 
Figure 1. Book Types

\begin{tabular}{|l|l|l|l|}
\hline \multicolumn{1}{|c|}{ Book Type } & \multicolumn{1}{|c|}{ Content } & \multicolumn{2}{c|}{ Publisher } \\
\hline Textbook & $\begin{array}{l}\text { Summarizing existing } \\
\text { knowledge for educa- } \\
\text { tional purposes within } \\
\text { academic organizations }\end{array}$ & $\begin{array}{l}\text { Organizational } \\
\text { Structure/Affiliations } \\
\text { stitutions, commercial } \\
\text { entities, independent } \\
\text { presses }\end{array}$ & $\begin{array}{l}\text { Main Specified } \\
\text { Target Audience }\end{array}$ \\
\hline $\begin{array}{l}\text { University } \\
\text { Press }\end{array}$ & $\begin{array}{l}\text { Producing new academic } \\
\text { knowledge }\end{array}$ & $\begin{array}{l}\text { Institution of higher } \\
\text { learning }\end{array}$ & Academic peers \\
\hline $\begin{array}{l}\text { Commercial } \\
\text { Academic Press }\end{array}$ & $\begin{array}{l}\text { Producing new academic } \\
\text { knowledge }\end{array}$ & $\begin{array}{l}\text { Large commercial } \\
\text { entity }\end{array}$ & Academic peers \\
\hline $\begin{array}{l}\text { Commercial } \\
\text { Popular Press }\end{array}$ & $\begin{array}{l}\text { Popularizing existing } \\
\text { knowledge or dissemin- } \\
\text { ating provocative ideas }\end{array}$ & $\begin{array}{l}\text { Large commercial } \\
\text { entity }\end{array}$ & Popular audiences \\
\hline $\begin{array}{l}\text { Small Press } \\
\text { Agenda }\end{array}$ & $\begin{array}{l}\text { Producing new know- } \\
\text { ledge and disseminating } \\
\text { provocative ideas }\end{array}$ & $\begin{array}{l}\text { Small independent enti- } \\
\text { ties and affiliations to } \\
\text { specific political groups }\end{array}$ & $\begin{array}{l}\text { Specific political } \\
\text { communities and } \\
\text { academic peers }\end{array}$ \\
\hline $\begin{array}{l}\text { Small Press } \\
\text { Nonagenda }\end{array}$ & $\begin{array}{l}\text { Producing new know- } \\
\text { ledge and disseminating } \\
\text { ideas }\end{array}$ & $\begin{array}{l}\text { Small independent } \\
\text { entity }\end{array}$ & Popular audiences \\
\hline
\end{tabular}

disciplinary knowledge (or indeed, new interdisciplinary fields as they emerge). Nevertheless, Burawoy (2004:266) contends that students can be thought of as "our first and captive public" who leave the university as "ambassadors of sociology to the wider world." As an increasingly large proportion of the total population attends university, an argument could be made that textbook writing is a type of public academic labour (Brym and Nakhaie, this issue).

In small culturally and economically dependent nations lying outside the core of the global academic division of labour, textbooks often play a nation building role, for example, as Canadian, New Zealander, Australian, Lithuanian, or Swedish scholars attempt to forge a national version of academic scholarship, particularly in the social sciences and humanities (Crothers 2008; Platt 2008). However, the explicit professional goal of textbooks - to train future scholars who will replenish and reproduce disciplinary ranks - clearly distinguishes them from other genres of books. Textbooks are not generally sold outside academic bookstores and their sale is typically mandated as a requirement to pass a course (in this sense, students are truly a "captive" audience). Therefore, textbook writing is a distinctive form of academic labour worth special categorical distinction, outside of the core academic and public book writing genre that we are primarily concerned with in our analysis. In contrast to our other analytical categories, which are defined on the basis of publisher, we categorize textbooks on an assessment of book content and audience. Since textbook writing is a valuable professional activity that reaches 
a large audience of undergraduate students, we believe that defining this form of scholarly production as "public" academic work belies the specific institutional and market dynamics (the books are chosen by professors, not citizens or consumers) that shape undergraduate education in modern Western universities.

Books published by university presses represent a clear example of Burawoy's "professional" academic labour. Publishing a book through a university press often ranks as the pinnacle of success and prestige in one's academic career. A book published under a university press banner carries with it an explicit link to an academic institution and the distinction of having endured the expert scrutiny of a peer-review process that is endorsed by the university itself. These books tend to be thought of as representing the professional "gold standard" in academic book publishing, especially when the press is run by a prestigious university (for example, University of Chicago or California in the United States, or University of Toronto or McGill-Queens in Canada). ${ }^{3}$ In relation to our empirical focus on audience as the key variable for distinguishing different types of public academic work, the important issue to note is that university press books are manufactured and marketed for consumption among academic peers. The content of such books generates new knowledge within the discipline or on interdisciplinary topics (we know from the existing literature that academic books tend to be far more interdisciplinary in their orientation than academic articles, see Clemens et al. 1995) and addresses the most compelling "puzzles" or problems as defined by professional research programs. This is true despite the fact that some academic press books can reach a broad popular or policymaking audience. A good example is John Porter's 1965 book The Vertical Mosaic (see Helmes-Hayes' contribution, this issue), an extraordinary book (despite its limitations) that did professional, public, and policy work simultaneously.

Despite the high status of university press books, they do not have a monopoly on the academic marketplace and the professional academic work that is produced in book form. Numerous commercial presses, such as Routledge and Praeger, specifically target academic audiences and publish titles that are considered professional works of high quality. Like university press books, commercial academic press books are predominantly found in academic bookstores, though they can also be found in lar-

3. We leave aside, for now, the all-important question of whether the prestigious university label ensures quality and excellence, or is part of what sociologist Robert Merton (1968) called the "Matthew effect." There is simply no universally valid way to measure quality of scholarship, since the status of a press or the journal can be part of a legitimating process and status competition as well as a measure of quality. High quality works and ideas can be published in low status journals or presses; there simply is no way to "measure" this; therefore the kind of research we are doing here is ultimately data to be discussed and debated as much as anything else. 
ger commercial establishments or independent book stores in university or college towns and large cities. While books published via commercial academic publishers are ostensibly products of professional labour, they are differentiated from academic press books in a number of ways. As Greco (1997) shows, these books tend to be priced higher, with more attention given to marketing and presentation. Commercial presses can direct more capital towards monitoring market trends, building ties with book vendors, and developing innovative sales strategies, but their books lack the explicit connection to a prestigious institution of higher learning. In the US, some deans and academic vice presidents tend to "view university presses more 'positively' than commercial academic presses in the rigorous tenure process" (1997:15). Thus, many academics seek to publish their research in university presses over commercial presses with the aim of getting hired and earning tenure, promotions, or salary increases (1997:15). Accordingly, we believe that commercial academic presses are often seen as less prestigious outlets to publish professionally.

In the Canadian context, where the market for university press books is smaller and heavily subsidized by the state, one could make the case that the distinction between academic books published by commercial academic presses and those published by university presses is less clear cut. Still, Canadian academics share the general norm that places university press books at the top of the status hierarchy of book publishing. ${ }^{4}$

In this analysis we are concerned with the distinction between commercial academic and commercial popular presses, since this is the key division between professional and public audiences. In contrast to the professional aspirations of commercial academic presses, commercial popular presses such as Macmillan or HarperCollins publish titles that cover a broader range of genres, including fictional literature, and are meant to appeal to a wider range of audiences. Accordingly, commercial popular presses are much less likely to publish works that appeal to a narrowly defined market segment such as professional academics. Instead, authors are encouraged to dispense with technical jargon and embrace arguments that are straightforward and easily grasped (Myers 2004; Greco et al. 2007). Commercial popular presses choose books and topics that are marketable and have the potential to sell in larger quantities. This goal is usually aided by more extensive marketing and advertising which means that books published by commercial popular presses

4. The boundary between respectable commercial academic presses where market sales are important but peer review processes are relatively rigorous and "vanity presses" that are run largely on a "pay as you go" basis is an issue that tenure and promotion committees across Canada must deal with all the time. For this project, we did not create a separate category for works produced by vanity presses. They are included in the small press categories. 
are more likely to be reviewed in newspapers and magazines or featured in television or radio broadcasts, sometimes accompanied by interviews or appearances by the author. These activities give this type of publication - and its author - much greater exposure to the wider public than enjoyed by commercial academic or university presses. Thus, commercial popular presses appear to be the most appropriate medium through which to produce books for public consumption and to engage in what Burawoy calls "traditional" public intellectual endeavours. Commercial popular press books traditionally earn less professional prestige within academia because their target audience is the nonprofessional reader.

Similarly, books published via small independent presses are not traditionally held in high professional regard, although this prejudice has been contested as outsiders to mainstream intellectual traditions (e.g. feminists, Marxists, black nationalists, or indigenous scholars, particularly after the 1960s) attempted to gain a beachhead in university life (Merton 1972). Over and above these professional battles concerning definitions of quality academic work, publishing through a smaller press might also suggest the author's desire to be a public intellectual. Drawing from Burawoy's distinction between traditional and organic public sociology, one may interpret the writing of a small press text as practising the latter type of public sociology. According to Burawoy, the traditional public sociologist speaks to widely dispersed collectivities in the mainstream - "thin" publics - which are characterized by the absence of organization and collective identity. As suggested above, typical forums for this type of academic labour include journalistic writing, television appearances, and the mass produced commercial book. In contrast, the organic public sociologist interacts with locally embedded and politically cohesive communities - or "thick" publics — that engage dialogically with the sociologist to constitute their public identities and render visible their specific struggles. While traditional public sociology introduces broader questions into public discourse via the mainstream mass media, organic public sociology finds its voice in smaller publishers, such as Fernwood Publishing, Between the Lines, or South End Press, which are run by scholars and editors motivated by specific political agendas that are connected, explicitly or implicitly, to grassroots social movements.

Nevertheless, many small presses hold no specific political agendas and do not have particular links to thick publics. For this reason, we distinguish between those small presses with clear political or ideological agendas and those without. Examples of nonagenda small presses in our sample are Acorn Press or Mosaic Press. Another concern with this "organic" assumption is that publishing with smaller presses may feasibly serve what Burawoy calls instrumental rather than reflexive ends. Argu- 
ably, small presses may provide an academic with a quick outlet in which to publish without a lengthy review process. In this way, the small press serves less of an outlet for politically motivated public scholarship than as a largely professional pathway towards tenure, promotion, and general career advancement. Small ideologically driven presses in Canada may, in fact, play similar roles in the book production and distribution system that larger and more prestigious presses do in larger markets such as the United States and Great Britain, as academic scholarship is produced according to the social, political, cultural, and economic dynamics of the society in question.

To examine the relationship between scholarly status and various types of book publishing within disciplines, we procured a random sample of scholars from the three disciplines with which we are concerned (sociology, political science, and economics) using a dataset originally compiled for Siler and McLaughlin's (2008) article "The Canada Research Chairs Program and Social Science Reward Structures." Since the aim of that article was to compare the reward structures in Canadian sociology, political science, and economics in relation to appointments of the Canada Research Chair (CRC) program, the Siler-McLaughlin dataset has the added advantage of containing information on both a randomly sampled segment of professors and a high status elite in each discipline. A sample of CRC holders from 1999-2004 in the disciplines of sociology $(\mathrm{N}=18)$, political science $(\mathrm{N}=17)$, and economics $(\mathrm{N}=14)$ plus a random sample of non-CRC holders in sociology $(\mathrm{N}=80)$, political science $(\mathrm{N}=71)$, and economics $(\mathrm{N}=69)$ comprises the dataset.

The dataset supplies information on academic publication and citation counts from the top Canadian journals (two in sociology, and one each in political science and economics ${ }^{5}$ ) as well as the top three and top twenty journals in each respective discipline for both CRCs and the random sample (non-CRCs). The top journals were selected using prominent published rankings of journals within the three disciplines (see Appendix B). Data on publication and citation histories was acquired from publicly available curriculum vitae and other online sources such as Sociological Abstracts, EconLit, and the Web of Science. Following Siler and McLaughlin, we used the citation and publication counts as measures of academic status.

Although publication and citation counts in and of themselves do not represent a measure of the quality of work, using a variety of prestige or

5. The two top journals in Canadian sociology are The Canadian Journal of Sociology and The Canadian Review of Sociology and Anthropology (now called The Canadian Review of Sociology). Together they produce about the same number of articles per year as the top journals in political science (The Canadian Journal of Political Science) and economics (The Canadian Journal of Economics). 
influence measures mitigates that to some extent. It seems reasonable to assume that the majority of top scholars (i.e., those with higher status) working in Canadian universities will have published, or at least be cited, in the top Canadian journal in their respective fields. Nevertheless, the Canadian journals are not the top journals in any of the disciplines we are studying, given the status of international, particularly American, journals in the contemporary social sciences. Therefore, we have included the top three journals overall for each discipline in our measures, as determined by widely used criteria in the respective fields. This produces an American bias, but the United States has the largest number of scholars working in each of the fields we are looking at, and is home to many of the world's top universities, research facilities, and other academic and intellectual resources. This in turn attracts many of the world's top scholars and helps explain why a disproportionate number of prestigious journals are based there. Another potential difficulty in our research design may be posed by the case of specialists who publish mainly in smaller journals of very specific focus. In studying public intellectuals and their relationship to the "core" of their respective disciplines, it is reasonable to ask, if one is considered either high status or a public intellectual, whether at least a portion of his or her scholarly output is published or cited in one of the top journals in the field as a whole. The tendency of some scholars to publish in specific subdisciplinary areas is captured to some extent in the measure we have of the top 20 journals in each discipline, as it is likely that some of these journals tend to be more specialized and cater to the major subareas within each discipline.

In addition to publication and citation counts in top journals, the comparative samples of CRC and non-CRC attainment give us a third practical measure of status among sociologists, political scientists, and economists. Using several different measures of disciplinary status helps avoid the biases that would flow from the use of one type of indicator. Thus, we added three other status-related variables to the original dataset. The first is the Gourman Report score (Gourman 1997) for the university each professor in our sample is affiliated with. The Gourman report gives each university a rating between one and five, providing a quantitative measure of the quality of each institution. In our sample, McGill had the highest rating (4.64) and St. Francis Xavier had the lowest (2.65). Although Gourman has been criticized for not fully disclosing his ranking methodology, the Gourman Report has been widely used in academic research (Judge et al. 1995; O'Reilly and O'Reilly 1987).

The second institutional variable is a dummy variable signifying proximity to one of Canada's three major metropolitan centres. This variable is coded " 1 " if the university is located in the Greater Toronto 
Area, ${ }^{6}$ Montreal, or Vancouver. ${ }^{7}$ This distinguishes between the "metropolis" as a major centre of educational, political, and economic power and the "hinterlands." From this perspective, Canada's "big cities" may offer more opportunity for academics to engage the public since there is a higher concentration of media, publishers, audiences, and powerful social networks in those cities. Although the specific measures in the Maclean's rankings of Canadian universities have been widely criticized, particularly by university administrators, the basic categories of three types of universities seem reasonable, so we used this typology as a third institutional measure. We used the categories of research intensive medical/doctoral, comprehensive, and undergraduate teaching universities to look for patterns between institutional location and book writing.

Again using the original sample sets, we compiled individual book publication histories using information from curriculum vitae and online search engines such as WorldCat.org and Amazon.com. However, determining what counts as a "book" was no simple matter. Academic disciplines are fields of power where status hierarchies are contested. Since academics are rewarded for book publishing as well as article writing, scholars are always manoeuvring to define what they write as "real" books, even though some publications do not go through traditional peer-review publishing processes or, in the digital information age, even binding. To filter out works such as think tank monographs, policy reports, dissertations, and theses, which are not understood as "books" in the conventional sense, we employed three defining criteria. A book was counted only if 1) it was over 100 pages long; 2) it had an ISBN number; and 3) was either self-published or published through a printing house. The downside of this definition is that it removed from our sample a number of small press books in the 80-90 page range. As a result, small press book publishing may be underrepresented in our sample. Overall, we think this selection criteria focuses our analysis on manuscripts that represent the partially socially constructed category "book" as understood by tenure and promotion committees, libraries, and book stores.

In relation to the technical details of this kind of research, with few exceptions ${ }^{8}$ we tallied only the first edition of books with multiple edi-

6. This includes McMaster University. Although Hamilton is not technically in the GTA, it is tightly integrated with the region.

7. David Nock makes the case that being in Ottawa is relevant when looking at academics and their networks, and we certainly think this is the case for public and policy academic work. We have left this issue aside for now, although we believe addressing the role of national capitals in public academic work is vitally important.

8. For example, where a number of years stand between editions and/or there is evidence to suggest that the work has been significantly altered (if the title includes "Revised," say). 
tions in an attempt to ensure consistency. ${ }^{9}$ For practical reasons, we also decided to leave out publications that were unrelated to the scholar's disciplinary research, although we believe that this is a topic that could be productively followed up in the future. ${ }^{10}$ Co-authorship presented a further problem for individual book counts, which was dealt with by assigning "author credits." A single authored book counts as one author credit, a book with two authors counts as one half credit for each author, a book with three authors as one third credit, and so on.

The decision of book category was based on an assessment of several criteria: content summaries as provided on Amazon.com, information pertaining to the publisher's corporate structure and institutional affiliations, publisher mission statements that indicated any guiding or ideological principles, and reviews of back catalogues that could speak to the favoured target audiences of the publisher.

As the overall number of professors with books published is small and this number is further reduced when the data are broken down into our categories of interest, complex methods such as regression analysis cannot be used effectively. Therefore, this exploratory analysis will be kept simple and descriptive. Our analysis will proceed by comparing the distributions and means of book publishing with our various measures of status. Several of our variables are counts (books, publications, and citations) with abnormal frequency distributions. Comparison of means via t-tests is inappropriate in such cases, therefore the Wilcoxon-MannWhitney rank sum test is used.

\section{Results: Comparing Canadian Sociology, Political Science, and ECONOMICS}

As can be seen in Figure 2, political science professors write the most books on average, followed by sociologists and then economists. Table 1 shows a detailed breakdown of mean author credits for the different book categories by discipline. Scholars are least likely to publish popu-

9. There is also the thorny issue of authors changing from edition to edition or when an author comes aboard for later editions of an established series. The amount of author responsibility is unclear in these cases. In the first case, we have counted and coded only the first edition and in the second case we have counted and coded their authorship as normal. Finally, there is the problem of simultaneously published editions or versions by two different publishers (e.g., one Canadian and one American). In these cases, we coded the first publisher listed.

10. While we have some data on these publications, they could not be included in our sample count because the disciplinary character of books helped to determine the identity of the author when we were dealing with common name cases. A fuller analysis of nonacademic publishing by academics would require a very time-consuming data gathering strategy. 


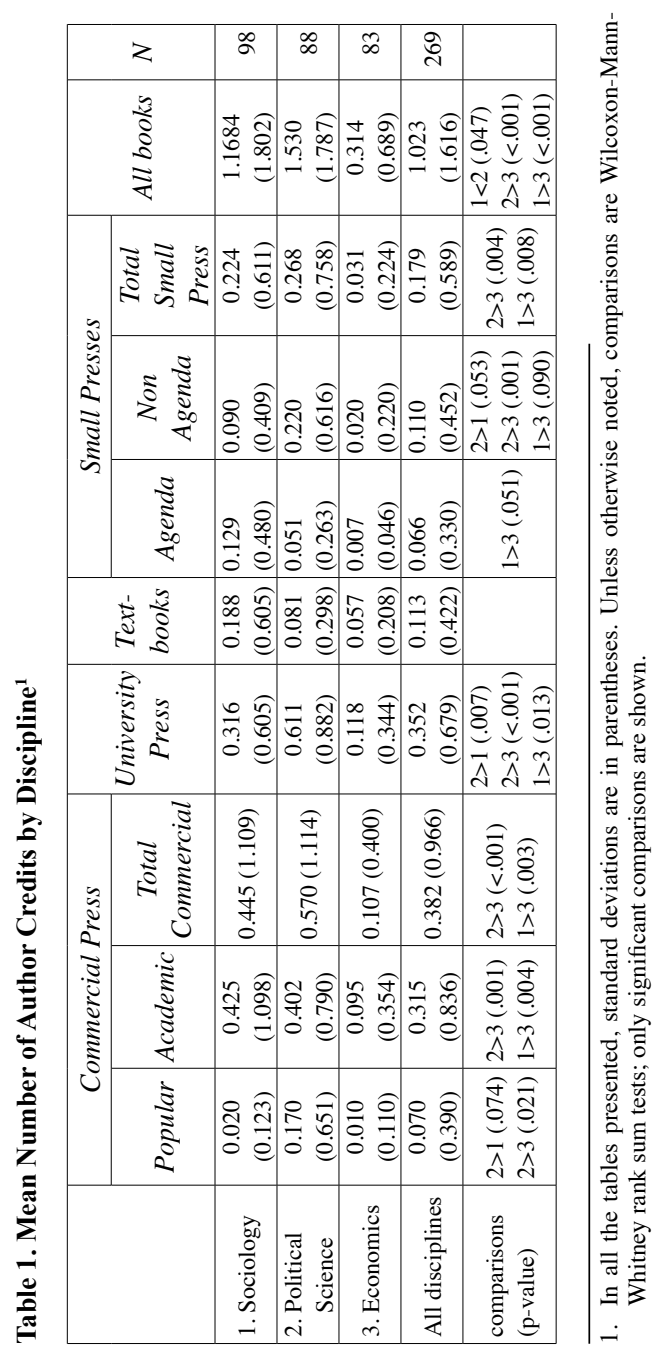


lar commercial press books and small press agenda books. Textbooks make up only a small portion of total books published, and there is no difference in the average number of textbooks published by professors in the various disciplines. Only political scientists regularly produce books via popular commercial presses. Most of the books produced in each discipline have an academic focus, being published through either commercial academic presses or university presses.

Figure 2. Mean Total Author Credits by Discipline

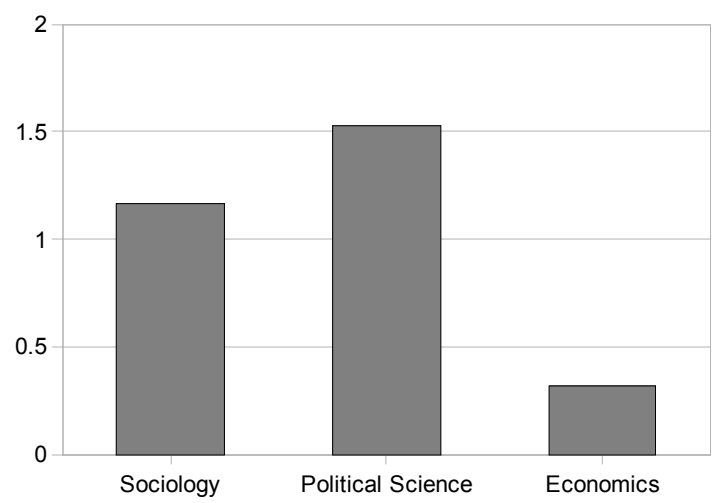

Looking at Table 2, economists, followed by sociologists and political scientists, lead in the average number of publications in journals. Economists are especially likely to publish in the top 20 journals in their field compared to sociologists and political scientists. There is no substantial difference among the disciplines in terms of number of citations. ${ }^{11}$

Table 2: Mean Number of Journal Publications/Citations by Discipline

\begin{tabular}{|c|c|c|c|c|c|c|c|}
\hline & \multicolumn{3}{|c|}{ Publications } & \multicolumn{3}{|c|}{ Citations } & \multirow[t]{2}{*}{$N$} \\
\hline & $\begin{array}{c}\text { Top 2/1 } \\
\text { Can }\end{array}$ & Top 3 & Top 20 & $\begin{array}{c}\text { Top 2/1 } \\
\text { Can }\end{array}$ & Top 3 & Top 20 & \\
\hline 1. Sociology & $\begin{array}{c}0.910 \\
(1.839) \\
\end{array}$ & $\begin{array}{c}0.110 \\
(0.403) \\
\end{array}$ & $\begin{array}{c}0.460 \\
(0.839) \\
\end{array}$ & $\begin{array}{c}3.704 \\
(11.157) \\
\end{array}$ & $\begin{array}{c}1.673 \\
(4.644) \\
\end{array}$ & $\begin{array}{c}4.592 \\
(10.408) \\
\end{array}$ & 98 \\
\hline $\begin{array}{l}\text { 2. Political } \\
\text { Science }\end{array}$ & $\begin{array}{c}0.490 \\
(1.184) \\
\end{array}$ & $\begin{array}{c}0.080 \\
(0.460) \\
\end{array}$ & $\begin{array}{c}0.270 \\
(0.769) \\
\end{array}$ & $\begin{array}{c}3.591 \\
(8.228) \\
\end{array}$ & $\begin{array}{c}0.864 \\
(2.030) \\
\end{array}$ & $\begin{array}{c}3.193 \\
(6.762) \\
\end{array}$ & 88 \\
\hline 3. Economics & $\begin{array}{c}0.730 \\
(1.170)\end{array}$ & $\begin{array}{c}0.650 \\
(1.365)\end{array}$ & $\begin{array}{c}2.69 \\
(5.212)\end{array}$ & $\begin{array}{c}2.337 \\
(6.129)\end{array}$ & $\begin{array}{c}2.578 \\
(6.692)\end{array}$ & $\begin{array}{c}14.554 \\
(44.272)\end{array}$ & 83 \\
\hline All disciplines & $\begin{array}{c}0.720 \\
(1.459) \\
\end{array}$ & $\begin{array}{c}0.270 \\
(0.874) \\
\end{array}$ & $\begin{array}{c}1.090 \\
(3.149) \\
\end{array}$ & $\begin{array}{c}3.245 \\
(8.882) \\
\end{array}$ & $\begin{array}{c}1.688 \\
(4.828) \\
\end{array}$ & $\begin{array}{c}7.208 \\
(25.006) \\
\end{array}$ & 269 \\
\hline $\begin{array}{l}\text { comparisons } \\
\text { (p-value) }\end{array}$ & $\begin{array}{l}1>2 \\
.019 \\
3>2 \\
.019 \\
\end{array}$ & $\begin{array}{ll}3>1.001 \\
3>2 & .001\end{array}$ & $\begin{array}{l}1>2.029 \\
3>1.001 \\
3>2.001\end{array}$ & $1>3.066$ & - & $3>2.082$ & \\
\hline
\end{tabular}

11. The high score (14.554) for citations in top 20 journals for economists is the result of a single influential case. 
These findings suggest that in each discipline the professional group is strongest and the public academic proponents are somewhat weaker. Moreover, we can determine for each discipline whether the norm is to publish journal articles or books. Economists are more likely to publish in journals, while political scientists have a greater inclination to write books. Sociologists are in the middle on this measure. It is possible that the propensity for economists to publish more articles in journals compared to books is related to the dominance of quantitative methodologies in that discipline and the extent to which academic publishing in the discipline is based on a science model. ${ }^{12}$

The tables above can be considered the "raw" or "base" results; we will now focus more closely on how these data are affected by control variables.

\section{Gender}

In our sample, the ratio of females to males was almost 1:1 in sociology. Males outnumber females by a 2:1 margin in political science, and 14:1 in economics. Within sociology, males publish, on average, more university press books $(0.432$ vs. $0.175, \mathrm{p}<.054)$ and more total books $(1.420$ vs. $0.450, \mathrm{p}<.008)$ than females but there are no significant differences in journal publications and citations. This is a counterintuitive finding in the context of the sociology of sociology in Canada, since in a study of the most cited books in Canadian sociology Nock (2001) found that women were more likely than men to publish highly cited books compared to journal articles. The reason for this, according to Nock, is that books are more suited to qualitative methodologies. Nock's findings may apply best to the elite within the discipline, or to the founding generation of 1960s and 1970s era sociologists, before the professionalizing processes of recent decades which have resulted in journal rather than book publishing leading to more gender equality. Nevertheless, bearing in mind that we are not looking at the most cited books (as did Nock) but total books, we did not find that female professors in sociology had a preference for book publishing over article publishing. This might be explained by the fact that female professors in our sample were at an earlier point in their careers than males, averaging 13.3 year since receiving a $\mathrm{PhD}$ compared to 19.0 for males $(\mathrm{p}<.001)$ and book publishing is positively associated with number of years since $\mathrm{PhD}$. In other words, senior professors are more likely to have published books and more of the senior professors in our sample were male. It is possible

12. Nock (2001) and Clemens et al. (1995) suggest that qualitative methodologies are well suited to the book format. 
that the average quality and number of citations of the books published by female professors is higher than for their male counterparts, but we did not measure the quality of books or number of citations of books. In political science, in contrast to sociology, while males have on average more citations than females, there are no gender differences among book or article publications.

\section{University Status}

There is no difference in the Gourman Report ratings of universities among those who have published books and those who have not; however, there is a slight positive relationship between Gourman Report scores and number of publications and citations. This likely reflects the importance of publishing in journals for landing tenure-track positions at the most prestigious universities. The universities in the Greater Toronto Area, Montreal, and Vancouver average higher ratings in the Gourman Report than universities in the rest of the country $(3.8$ vs. $3.2, \mathrm{p}<.001)$. Consequently, it is not surprising that for the combined disciplines, professors working in the Greater Toronto Area, Montreal, and Vancouver have, on average, more publications and citations than others. However, when broken down by discipline, we found no metropolis-hinterland differences in publications or citations within sociology. With respect to books published by commercial presses, there is no difference between those working in the major metropolitan areas and those in other areas. Political scientists and economists in the largest urban centres publish, on average, more books with university presses (economics $\mathrm{p}<.039$, political science $\mathrm{p}<.037$, sociology $\mathrm{p}<.336$ ). Overall, there are only minor differences in all forms of publishing between the most prestigious universities and the rest, as measured by Gourman Report ratings and the metropolis-hinterland distinction. This speaks perhaps to the relatively "flat" structure of universities in Canada (Davies and Hammack 2005; McLaughlin 2005).

Utilizing Macleans' categories to rank universities, there are some interesting but not unexpected findings with regard to book publishing and status. The greater prestige and research focus of medical/doctoral universities is evident as professors at those universities average more citations in the top 3 and top 20 journals in their respective fields than professors at primarily undergraduate universities. Again, this is especially pronounced in economics, where professors at medical/doctoral universities average many more citations (22.38) than those at comprehensive universities (8.42). Due to the very low number of books published, there are no patterns found with respect to book publishing 
using the Macleans' university categories. However, there is a significant finding within sociology and political science. Within each of these disciplines, professors at medical/doctoral universities have published, on average, twice the number of books with university presses (see Table 3) compared to those at comprehensive or primarily undergraduate universities. For other types of books, there are no differences among the three categories of universities. This is a clear indication that books published by university presses are more highly valued within the academic profession than other types of books.

Table 3. Mean University Press Author Credits by Discipline and Type of University

\begin{tabular}{|c|c|c|c|}
\hline & Type of university & University Press & $\begin{array}{c}\text { Comparisons } \\
(p \text {-values })\end{array}$ \\
\hline \multirow{3}{*}{ Sociology } & medical/doctoral (1) & 0.48 & $1>2, \mathrm{p}<.043$ \\
\hline & comprehensive (2) & 0.21 & \multirow{2}{*}{$1>3, p<.021$} \\
\hline & undergraduate (3) & 0.18 & \\
\hline \multirow{3}{*}{ Political Science } & medical/doctoral (1) & 0.89 & $1>2, p<.101$ \\
\hline & comprehensive (2) & 0.41 & \multirow{2}{*}{$1>3, p<.031$} \\
\hline & undergraduate (3) & 0.32 & \\
\hline
\end{tabular}

\section{Canada Research Chairs}

Professors holding Canada Research Chairs publish and are cited more on average than others with one interesting exception. While Canada Research Chairs in sociology publish in the top three journals more, on average, than others in their field, they do not publish more than others in the top Canadian journals. This is not the case in political science, where there is no difference between Canada Research Chairs and others in publishing articles, or economics, where Canada Research Chairs are likely to have more publications in the top three journals and in the top Canadian journal than others. In economics, CRCs have, on average, more publications and citations and publish more university press books. Among political scientists, CRCs have, on average, more commercial press books, both academic and popular, as well as more university press books. They also average more citations in journals than non-CRCs. There is no difference in book publishing between CRCs and non-CRCs in sociology.

Political science thus not only outpaces sociology in the production of books (recall Figure 2), but also seems to reward book authors more than sociology. From Table 4 it can be seen that no political scientist had been awarded (at the time of our data collection, at least) a Canada Re- 
Table 4. Professors Who Have Written At Least One Book, by Discipline and Whether They Hold a Canada Research Chair

\begin{tabular}{|c|c|c|c|}
\hline \multicolumn{4}{|c|}{ Sociology } \\
\hline & \multicolumn{2}{|c|}{$C R C$} & \multirow{2}{*}{ Total (\%) } \\
\hline & Yes $(\%)$ & $\mathrm{No}(\%)$ & \\
\hline Book & $12(66.7)$ & $39(48.8)$ & $51(52.0)$ \\
\hline No book & $6(33.3)$ & $41(51.3)$ & $47(48.0)$ \\
\hline Total & 18 & 80 & 98 \\
\hline
\end{tabular}

Political Science

\begin{tabular}{|l|l|l|l|}
\hline \multirow{2}{*}{} & \multicolumn{2}{|c|}{ YesC $(\%)$} & \multirow{2}{*}{ Total (\%) } \\
\cline { 2 - 4 } & \multicolumn{1}{|c|}{ No $(\%)$} & \\
\hline Book & $17(100)$ & $43(60.6)$ & $60(68.2)$ \\
\hline No book & $0(0)$ & $28(39.4)$ & $28(31.8)$ \\
\hline Total & 17 & 71 & 88 \\
\hline
\end{tabular}

Economics

\begin{tabular}{|l|l|l|l|}
\hline \multirow{2}{*}{} & \multicolumn{2}{|c|}{ Yes (\%) } & \multirow{2}{*}{ Total (\%) } \\
\cline { 2 - 4 } & \multicolumn{1}{|c|}{ No $(\%)$} & \\
\hline Book & $5(35.7)$ & $20(29.0)$ & $25(30.1)$ \\
\hline No book & $9(64.3)$ & $49(71.0)$ & $58(69.9)$ \\
\hline Total & 14 & 69 & 83 \\
\hline
\end{tabular}

search Chair without having authored or co-authored at least one book. In contrast, 33\% of Canada Research Chairs in sociology are awarded to professors who have not published a book. Overall, just over half of sociologists have published at least one book while more than two-thirds of political scientists have. Less than one-third of economists have published a book.

\section{Popular Commercial Press Books}

Since our interest is in public intellectuals, we now take a closer look at book publishing with commercial presses - the type of book most likely to reach a wider public audience. Comparing those who have published books via popular commercial presses with the rest of the sample, it can be seen that these authors are more likely to have had a PDD longer (Table 5).

Table 5: Years since PhD for Those Who Have Published Popular Commercial Press Books Compared to Those Who Have Not.

\begin{tabular}{|l|c|c|}
\hline & Years since PhD & $N$ \\
\hline Commercial popular book & $27.667(9.019)$ & 12 \\
\hline No commercial popular book & $16.891(10.967)$ & 257 \\
\hline$t$ test (p-value) & .001 & 269 \\
\hline
\end{tabular}


Those who have published commercial press books have also, on average, written more books total, and have written more university press books (Table 6). It is important not to make too much of these findings, since we must remember that in our sample only twelve individuals have written popular commercial press books: three sociologists, eight political scientists and one economist. Of the twelve, seven were affiliated with schools near major centres and five were not. All seven located in major centres were political scientists. Four held Canada Research Chairs. All were political scientists. As there are only three sociologists and one economist who have written popular commercial books, it is impossible to draw conclusions for those disciplines. Note that in Table 6 (as in Table 2) the difference for top 20 citations is insignificant despite the rather large difference in means. This is because the Wilcoxon-MannWhitney test is not a direct test of the means but rather a comparison of the distributions. The mean for top 20 citations for those who have not published books with popular commercial presses is skewed due to one influential case with 366 top 20 citations.

Table 6: Mean Publications and Citations for Those Who Have Published Popular Commercial Press Books Compared to Those Who Have Not

\begin{tabular}{|l|c|c|c|c|c|c|c|}
\hline & \multicolumn{3}{|c|}{ Publications } & \multicolumn{3}{c|}{ Citations } & \\
\hline & $T 2 / 1$ & $T 3$ & $T 20$ & $T 2 / 1$ & $T 3$ & $T 20$ & $N$ \\
\hline $\begin{array}{l}\text { Commercial } \\
\text { book }\end{array}$ & $\begin{array}{c}0.670 \\
(.888)\end{array}$ & $\begin{array}{c}0.000 \\
(.000)\end{array}$ & $\begin{array}{c}0.330 \\
(.888)\end{array}$ & $\begin{array}{c}5.917 \\
(8.361)\end{array}$ & $\begin{array}{c}0.833 \\
(.937)\end{array}$ & $\begin{array}{c}2.917 \\
(3.964)\end{array}$ & 12 \\
\hline $\begin{array}{l}\text { No commer- } \\
\text { cial book }\end{array}$ & $\begin{array}{c}(1.720 \\
(1.481)\end{array}$ & $\begin{array}{c}0.280 \\
(.892)\end{array}$ & $\begin{array}{c}1.120 \\
(3.212)\end{array}$ & $\begin{array}{c}3.121 \\
(8.902)\end{array}$ & $\begin{array}{c}1.728 \\
(4.933)\end{array}$ & $\begin{array}{c}7.409 \\
(25.555)\end{array}$ & 257 \\
\hline $\begin{array}{l}\text { comparison } \\
\text { (p-value) }\end{array}$ & .564 & .166 & .309 & .015 & .337 & .354 & 269 \\
\hline
\end{tabular}

It appears that political scientists are more likely than economists and sociologists to earn status publishing popular books with commercial presses; 3 of the 8 political scientists who published commercial books held Canada Research Chairs at universities near major centres and only 2 did not have more than 25 years of experience. This "stage of career" variable crosses disciplines, since all of those who wrote commercial books in sociology and economics had held a $\mathrm{PhD}$ for more than 27 years. Of the 3 sociologists who published popular commercial books, each had his/her PhD for over 30 years. Curiously, the 3 have only 24 citations and 3 publications among them (all 3 in top Canadian journals). For comparison, the average total citations and publications for sociologists were 9.969 and 1.480 respectively. The 3 sociologists who had published popular commercial books were slightly below average in publications and citations. In contrast, the 8 political scientists who published 
with popular commercial presses differed from the rest of the political scientists on number of citations in the top Canadian political science journal with 7.5 citations compared to 3.2 for the others $(\mathrm{p}<.050)$. Thus, the significant difference for citations in the top Canadian journals seen in Table 6 is accounted for entirely by political scientists. The average number of years since receiving a $\mathrm{PhD}$ was again higher compared to other political scientists who have no popular commercial publications (25.375 vs. $15.288, \mathrm{p}<.012)$. Political scientists publishing with popular commercial presses had, on average, more books published with university presses as well. Combined with the finding above that Canada Research Chairs in political science also have, on average, more books published with popular commercial presses, our data provides support for the idea that it is high status individuals within the discipline of political science who are most engaged with the public. The sole economist in our sample who had published a book with a popular commercial press had no citations or publications in the journals we looked at.

From these data it is impossible to make firm conclusions; however, it seems that popular commercial press books are more likely to be published by experienced professors in all three disciplines. In the case of political science, these authors are more likely to be cited in the top Canadian political science journal which might indicate that popular press book authors in Canadian political science enjoy a high profile and high scholarly status, at least within the Canadian context. In comparison, the authors of books published via commercial academic presses and university presses are more likely to be cited in all types of journals. As well, their authors have, on average, more publications in the top Canadian journals. This is true in all three fields, but holds particularly true in sociology and political science. Although our analysis requires a larger sample in order to reach statistical significance, our preliminary findings suggest that political science, more than sociology and economics, is a discipline where the scholarly elite in the field are more rather than less likely to engage the public through book writing using commercial press outlets.

\section{Small Press Agenda Books}

If political science leads the traditional public academic sweepstakes via publishing books through commercial popular presses, sociology seems to be the leader in writing books for agenda-oriented small presses, as we can see in Table 7. Sociologists are far more likely to write books for agenda-oriented presses, suggesting they are engaged much more than political scientists and economists in what Burawoy would call 
Table 7: Small Press Total Author Credits, by Discipline

\begin{tabular}{|l|c|c|c|}
\hline & Sociology & Political Science & Economics \\
\hline Agenda & 12.6 & 4.5 & 0.6 \\
\hline Nonagenda & 9.3 & 19.1 & 2 \\
\hline
\end{tabular}

"organic" public sociology. It is worth noting, of course, that the total number of small press books is actually greater in political science than in sociology, but it seems likely that the more "centrist" nature of Canadian political science compared to sociology (Nakhaie and Brym 1999; McLaughlin 2005; for a discussion on the left-hand nationalist presence in Canadian sociology see Cormier 2004) explains the different patterns in relations to publishing in small agenda presses, which often have politically radical agendas.

\section{Discussion}

Our analysis suggests that within the discipline of political science, it is the higher status professors who are most likely to take on the role of public intellectuals. As we do not have complete data for the full population of scholars in Canada in these fields, we cannot draw strong conclusions about commercial book publishing in sociology. However, the data suggest that authors of academic books in sociology are relatively privileged in terms of number of citations and publications compared to those who write commercial books. While the sociology professors in our sample who wrote popular commercial press books were, on average, older than others, they were about average in number of publications and citations and no more likely to hold a Canada Research Chair or a position at a prestigious university than political science or economics professors.

What might explain some of the disciplinary dynamics we have observed? Marketability and profit may explain the greater number of commercial press books published by political scientists compared to sociologists and economists. On the surface it would seem that there is simply a larger and more lucrative market for books on politics written by experts. Since commercial presses are motivated by profit, they cater to the market by publishing books with popular appeal. By comparison, economics at the university level is considered a highly technical or "dry" topic. We might conjecture that economics books with a wide popular appeal are more likely to deal with practical matters of personal finances and investing and do not require the expertise of a professor of economics but rather that of real-world business professionals. Greco, 
Rodriguez and Wharton's study (2007) of the American book publishing industry found that between 1989 and 2000, 5,615 books on finance and 4,811 in political science were published by commercial presses (both academic and popular). Comparatively, only 2,975 sociology and 2,974 economics titles were published during the same period. It might be that in the public's eye the disciplines of political science and economics are authoritative and the respective subject matters well-defined. In contrast, sociology is broader in its range of topics and subdisciplines. It has a low public profile and is generally less well understood by the public. Among those who have opinions about sociology, it is often grouped with the "soft" or "left wing" disciplines in the arts and humanities and thus lacks credibility or legitimacy compared to the more prestigious and established disciplines. Canadian sociology in particular has been noted to be less positivistic on the whole than American sociology (Gartrell and Gartrell 1996). If sociology is generally more left-wing than other disciplines, the market for sociological books may be somewhat more limited than for "mainstream" political science. Ironically, books may be a better medium for elucidating the qualitative sociological research that has led to the labelling of sociology as a soft science. Indeed, Clemens et al. (1995:479) note that "while books are more likely to use qualitative evidence, the most widely cited type of book presents quantitative results."

Although our findings show that, on average, male sociologists in Canada write more books, and more university press books, than female sociologists, some of Canadian sociology's most acclaimed works have been written by women - and surprisingly - in areas not necessarily considered mainstream by the general public. Two notable examples are Dorothy Smith's Porter Prize-winning The Everyday World as Problematic (1987), which was published by a university press (Northeastern), and Meg Luxton's More Than a Labour of Love: Three Generations of Women's Work in the Home (1980), which was published by a small press (The Women's Educational Press). Nock (2001:481-2) believes that the small presses inspired by Second Wave feminism created a new market for feminist books, which opened the door to greater acceptance by larger commercial and university presses. It can be seen in Figure 3 that all of the books in Hiller and Langlois' (2001) list of influential books in Canadian sociology, however, were published by large commercial presses or university presses. It is also notable that a number of them are specifically Canadian in focus and that several of them deal with feminism and gender.

Irrespective of these empirical findings, it is clear that sociology has historically covered a range of topics that could have broad public ap- 
Figure 3. The Most Important Books in English Canadian Sociology in the 20th Century (Hiller and Langlois, 2001)

Armstrong, Pat and Hugh Armstrong

1978 The Double Ghetto: Canadian Women and their Segregated Work. Toronto: McClelland and Stewart.

Boyd, Monica, John Goyder, Frank E. Jones, Hugh McRoberts, Peter C. Pineo and John Porter

1985 Ascription and Achievement: Studies in Mobility and Status Attainment in Canada. Ottawa: Carleton University Press.

Clement, Wallace

1975 The Canadian Corporate Elite. Toronto: McClelland and Stewart.

Clement, Wallace and John Myles

1994 Relations of Ruling: Class and Gender in Post-Industrial Societies. Montreal: McGill-Queens University Press.

Goffman, Erving

1959 The Presentation of Self in Everyday Life. Garden City, New York: Doubleday.

Guindon, Hubert

1988 Quebec Society: Tradition, Modernity, and Nationhood. Toronto: University of Toronto Press.

Hughes, Everett C.

1943 French Canada in Transition. Chicago: University of Chicago Press.

Lipset, Seymour Martin

1963 The First New Nation. New York: Basic Books.

Porter, John

1965 The Vertical Mosaic. Toronto: University of Toronto Press.

Smith, Dorothy

1987 The Everyday World as Problematic: A Feminist Sociology. Toronto: University of Toronto Press.

peal, for example, sexuality, race, mass media, or religion. ${ }^{13}$ With many tantalizing and commercially viable topics at its disposal, there is no doubt that Canadian sociology could be producing more and perhaps better quality books. It is telling that half of the past dozen recipients of the Porter Prize, the highest award of the Canadian Sociological Association (previously known as the Canadian Sociology and Anthropology Association), have come from outside the field, ${ }^{14}$ reflective of a general trend that has been a source of controversy within the CSA (Brym 2003). Is the fact that sociologists do not always win their own disciplinary award symptomatic of a problem within the discipline? Perhaps this speaks to the inherently multidisciplinary nature of sociology, or to the broad spectrum of topics and approaches that is considered sociologic-

13. Indeed, specifically on the topic of religion, we are sure to note recent and commendable efforts by Bibby (2004a; 2004b) and Kroeger and Nason-Clark (2004).

14. Source: Canadian Sociological Association online - http://www.csaa.ca/Awards/ AwardsPorter.htm - List of Past Recipients. 
al? In the results above we have seen that sociology professors holding positions at Canada's most prestigious universities publish and are cited more often in the top journals. However, there is no similar relationship for popular commercial press book publishing. Is there something about the culture and reward structure of the discipline that discourages the best scholars in the field from writing popular books? Should Canadian sociology reward book publishing more than it has? We conclude our paper by examining this issue.

Writing about American sociology, Clemens et al. (1995: 480) found that "books are more likely to be the coin of the realm at private institutions, while articles are the primary currency at public universities." Our results show something similar. In Canada, those most likely to have published books with university presses are scholars at Canada's elite medical/doctoral universities. However, the differences are not great; this probably reflects the relatively "flat" structure of Canadian universities (Davies and Guppy 1997; Davies and Hammack, 2005) compared to the more stratified American system (Burris 2004). Within Canadian sociology, there is clearly a preference for articles, in line with Clemens et al.'s association of public universities with the journal articles genre.

In terms of tenure and awards such as Canada Research Chairs in sociology, journal articles seem to be rewarded more highly than books. Among those who have published at least one book, the average number of years since receiving a $\mathrm{PhD}$ is 22.0 for sociologists compared to 18.6 for political scientists. In economics, where technical journal articles are the gold standard and book publishing is rare, the average number of years since receiving a $\mathrm{PhD}$ for book writers is 26.6. For Canadian sociologists, the shorter "tenure clock" than in the United States may work to discourage junior scholars from writing books in favour of publishing journal articles. It is simply too risky to "put all one's eggs in the same basket" by writing a book when a similar expenditure of academic labour could produce several journal articles. It may be that sociology professors at the beginning of their careers who must focus on publishing in journals simply continue this pattern after achieving tenure; however, this does not explain the political science case where it is more likely that experienced professors will turn to book writing. In American sociology too, those with the highest status tend to publish books. Phelan (1995) found that those who have become presidents of the American Sociological Association are prolific when it comes to publishing books but, on average, tend to publish relatively few journal articles.

Thus, professional rewards and incentives reveal only part of the story; other aspects of professional culture obviously influence the degree to which scholars are likely to produce books rather than articles. 
For example, the pressure on Canadian social scientists to secure funding through the Social Sciences and Humanities Research Council (SSHRC), which is based on a natural science model of applying for grants, likely encourages the production of research articles over longer term projects like books. Since political science depends on SSHRC funding as well, the professional culture within political science may not only encourage the writing of books, but encourage it at an earlier stage in one's career. A delicate balance must be achieved between academic rigour and professional needs on the one hand, and raising sociology's public profile on the other. Changing existing incentive structures such as tenure and promotion to better reward popular books aimed at a nonprofessional audience risks the erosion of professional standards and prestige. By the same token, raising sociology's public profile and improving its image in the public's eye through popular books could also lead to more status and prestige in an academic context while creating a larger space for sociology in the commercial publishing market.

Perhaps the discipline merely needs another catalyst, in the vein of John Porter's The Vertical Mosaic (1965), to inspire and cajole Canadian sociologists into writing professional books for publics at large. The publication of Porter's classic work was an epoch-defining moment (Brym with Fox, 1989), symbolizing the "coming of age" of sociology in Canada, which "essentially set the agenda for English-language Canadian sociology for the next fifteen to twenty years" (Helmes-Hayes and Curtis 1998:8). More than this, it sparked a public dialogue as it exposed the profound entrenched inequalities thought to be nonexistent in Canada's culturally pluralist society. The Vertical Mosaic remains the pinnacle for public sociology in Canada, yet it is worth noting that it was disseminated through professional channels via the University of Toronto Press. The unconventional path to public acclaim taken by Porter's text arguably reflects the unconventional route of Porter's own career (see Helmes-Hayes and Curtis 1998; Helmes-Hayes 2002). In an era when academic careers follow a more rigidly institutionalized path than in Porter's time, however, altering existing reward structures may provide better opportunities for sociological works to proliferate in the public sphere than waiting patiently for the discipline's next iconoclast.

Some might argue that sociology's current relatively low status within Canadian universities means there is little to lose. It remains a question for discussion and debate as to 1) the desirability of modifying incentive structures within the discipline to encourage more book writing (especially book writing for public audiences), and 2) what form any changes to incentive structures may take. As an example, lengthening the tenure clock to longer than five years might provide a greater win- 
dow of opportunity for those who wish to write books, but such a move might prove unpopular with many junior faculty who see the delay as yet another drag on their career aspirations in a profession that already has a long probationary period. These issues are worth discussing, in the context of a larger debate about how the incentive structure of Canadian sociology could be changed to encourage (or not) more public sociology, a dialogue that was institutionalized in the American context in a ASA committee on public sociology.

Taking measures to induce book writing in general is one issue, engaging in public sociology through the writing of popular commercial books is another. As we have seen, those most likely to have taken up this task are the most senior and high status political scientists. This appears to be a wise strategy for the discipline as a whole. After all, the discipline can only be well served by having its very best people represent it in the public sphere. The public face of Canadian sociology may be taking a different route, more "organic" in Burawoy's terms, through publication in agenda-based small presses. Although books published through such channels do not have as much chance of reaching "thin" or mainstream public audiences, they do elicit dialogue with "thick" publics. One explanation for this "organic" approach is that it is market driven. The United States, for example, presents a much larger market to publishers compared to Canada. In many cases, books written by academics - especially on Canadian topics - are simply not commercially viable in mass market books (politics notwithstanding). Small presses fill this niche. Another possibility is that radical, agenda-motivated sociologists are shut out of mainstream publishing and are making a space for themselves with small presses. If this is true, it represents what Burawoy would see as a problem; Canadian sociology pits its professional/ academic side against its critical/public side. The answer is surely not to muzzle sociology's "critical" side. As we have seen, some of the greatest successes in Canadian public sociology - again The Vertical Mosaic comes to mind - have had critical leanings. The key for sociology and its public image may be for us to bridge that gap with a heightened public role for the professional branch of sociology and its high-status members. In any case, we have offered empirical material here in the hope that this long-needed discussion and debate can be entered into on the basic of a solid understanding of some of the existing sociological dynamics and patterns that come into play within contemporary economics, political science, and sociology itself in the Canadian context. 


\section{REFERENCES}

Bibby, Reginald W. 2004a. Restless Churches: How Canada's Churches Can Contribute to the Emerging Religious Renaissance. Ottawa: Novalis. 2004b. Restless Gods. Ottawa: Novalis

Bourdieu, Pierre and Loïc Wacquant. 1992. An Invitation to Reflexive Sociology. Chicago: University of Chicago Press

Brym, Robert. 2003. The decline of the Canadian Sociology and Anthropology Association. Canadian Journal of Sociology 28(3):411-16.

Brym, Robert and Bonnie Fox. 1989. From Culture to Power: The Sociology of English Canada. Toronto, New York: Oxford University Press

Brym, Robert and M. Reza Nakhaie. 2009. Professional, critical, policy and public academics in Canada. Canadian Journal of Sociology (This volume).

Burawoy, Michael. 2005. For public sociology. American Sociological Review 70(Feb):4-28.

2004. Public sociologies: Contradictions, dilemmas, and possibilities. Social Forces 82(4):1603-1618.

Burris, Val. 2004. The academic caste system: Prestige hierarchies in Phd exchange networks. American Sociological Review 69(2):239-64.

Clemens, Elisabeth, Walter P. Powell, Kris McIlwaine, and Dina Okamoto. 1995. Careers in print: Books, journals, and scholarly reputations. The American Journal of Sociology 101(2):433-94.

Cormier, Jeffrey. 2004. The Canadianization Movement: Emergence, Survival and Success. Toronto: University of Toronto Press

Coser, Lewis, Charles Kadushin, and Walter Powell. 1982. Books: The Culture and Commerce of Publishing. New York, Basic Books.

Crothers, Charles. 2008. New Zealand sociology textbooks. Current Sociology 56(2):221-234.

Curtis, Bruce and Lorna Weir. 2002. The succession question in English Canadian sociology. Society/Société October.

Davies, S. and Neil Guppy. 1997. Fields of study, college selectivity, and student inequalities. Social Forces 73(4):131-151.

Davies, S. and F. Hammack. 2005. Channelling competition in higher education: Comparing Canada and the US. Journal of Higher Education 76: 89-106.

Gartrell, David C. and John W. Gartrell. 1996. Positivism in sociological practice: 1967-1990. Canadian Review of Sociology and Anthropology 33(2):143-158.

Gouldner, Alvin W. 1970. The Coming Crisis of Western Sociology. New York: Random House. 
Gourman, Jack. 1997. The Gourman Report (8th Ed). New York: Random House.

Greco, Albert N. 1997. The Book Publishing Industry (2nd Ed). New York: Routledge.

Greco, Albert N., Clara E. Rodriguez and Robert M. Wharton. 2007. The Culture and Commerce of Publishing in the $21^{\text {st }}$ Century. Stanford: Stanford University Press.

Helmes-Hayes, Rick. 2002. John Porter: Canada's most famous sociologist. The American Sociologist 33(1):79-104.

Helmes-Hayes, Rick and James Curtis. 1998. Introduction. Pp. 3-33 in R. Helmes-Hayes and J. Curtis, eds, The Vertical Mosaic Revisited. Toronto: University of Toronto Press.

Hiller, Harry and Simon Langlois. 2001. The most important books/articles in Canadian sociology in the twentieth century: A report. Canadian Journal of Sociology 26(3):513-516.

Hix, Simon. 2004. A global ranking of political science departments. Political Studies Review 2:293.

Judge, T.A., D.M. Cable, J.W. Boudreau, and R.D. Bretz. 1995. An empirical investigation of the predictors of executive career success. Personnel Psychology 48:485-519.

Kalaitzidakis, P. S. T. Mamuneas, T.P. 2002. Rankings of academic journals and institutions in economics. European Economic Association.

Luxton, Meg. 1980. More than a Labour of Love: Three Generations of Women's Work in the Home. Toronto: Women's Press.

Lynch, Michael. 2000. Against reflexivity as an academic virtue and source of privileged knowledge. Theory, Culture and Society 17(3):26-54.

McLaughlin, Neil. 2005. Canada's impossible science: Historical and institutional origins of the coming crisis in Anglo-Canadian sociology. Canadian Journal of Sociology 30(1):1-40.

McLaughlin, Neil and Kerry Turcotte. 2007. The trouble with Burawoy: An analytic, synthetic alternative. Sociology 41(5):813-828.

McLaughlin, Neil, Lisa Kowalchuk, and Kerry Turcotte. 2005. Why sociology does not need to be saved: Analytic reflections on public sociologies. The American Sociologist 36(3-4):133-51

Merton, Robert K. 1972. Insiders and outsiders: A chapter in the sociology of knowledge. The American Journal of Sociology 78(1):9-47. 1968. The Matthew effect in science. Science 159:56-63.

Myers, Charles T. 2004. A short tour of book publishing for political scientists. PS: Political Science and Politics. 37(3):489-491.

Nakhaie, M. Reza and Robert Brym. 1999. The political attitudes of Canadian professors. Canadian Journal of Sociology 24:329-53. 
Nason-Clark, Nancy and Catherine Clark Kroeger. 2004. Refuge From Abuse: Hope and Healing for Abused Christian Women. Downers Grove, IL: InterVarsity Press.

Nock, David A. 2001. Careers in print: Canadian sociological books and their wider impact, 1975-1992. Canadian Journal of Sociology 26(3):469485.

1992. Star wars: Aspects of the social construction of citations in AngloCanadian sociology. The Canadian Review of Sociology and Anthropology 29(3):346-61.

O'Reilly, Charles and Rosella O'Reilly. 1987. The Gourman report: Misinformation about the quality of graduate social work education. Research in Higher Education 27(1):85.

Phelan, Thomas J. 1995. Measures of success in American sociology. Sociological Forum 10(3):481-191.

Platt, Jennifer. 2008. British sociological textbooks from 1949. Current Sociology 56(2):165-182.

Porter, John. 1965. The Vertical Mosaic: An Analysis of Social Class and Power in Canada. Toronto: University of Toronto Press.

Siler, Kyle S. and Neil McLaughlin. 2008. The Canada Research Chairs Program and social science reward structures. Canadian Review of Sociology 45(1):93-119.

Smith, Dorothy E. 1987. The Everyday World as Problematic: A Feminist Sociology. Toronto: University of Toronto Press.

Swartz, David L. 2000. From critical sociology to public intellectual: Pierre Bourdieu and politics. Theory and Society 32(5-6):791-823.

Whitley, R. 1984. The Intellectual and Social Organization of the Sciences. Oxford, New York: Oxford University Press.

Wolfe, A. 1990. Books vs articles - Two ways of publishing sociology. Sociological Forum 5(3):477-89. 


\section{Appendix A}

Commercial Popular Presses

Macmillan, St Martin's Press

HarperCollins

Crown Publishing Group

Random House
Atlantic

McClelland \& Stewart

Little, Brown

Lester \& Orphen Dennys

University Academic Presses

University of Toronto Press

Princeton University Press

Syracuse University Press

University of Chicago Press
Oxford University Press

Cambridge University Press

Columbia University Press

\section{Commercial Academic Publishers}

Prometheus Books

Ashgate

Palgrave Macmillan

Greenwood Press/Praeger

Brill Academic Publishers

Routledge

Elsevier

SAGE Publications

Springer

Blackwell Publishing

Transaction/Aldine

Praeger Publishers

Polity Press

Rodopi

Lang

Lexington Books

Rowman and Littlefield

Brill

Lynne Pienner

Duncker \& Humblot

Klewer Academic Publishers

Captus Press
Continuum

Butterworths

Harvester Wheatsheaf

Athlone

DJØF Pub

Houghton Mifflin

de Sitter Publications

Harvester Press

Monthly Review Press

Copp Clark Pitman

Kraus International Publications

Hutchinson

Renouf Pub

South-Western Pub. Co

Paladin Grafton Books

Methuen

Avebury

Frank Cass

Gage

Hakkert

Tavistock Publications

Edward Elgar 


$\begin{array}{ll} & \text { Small Press (Agenda) } \\ \text { Paradigm Publishers } & \text { Broadview Press } \\ \text { Kumarian Press } & \text { Between the Lines } \\ \text { Arbiter Ring } & \text { Garamond Press } \\ \text { Black Rose Books } & \text { Fernwood } \\ \text { Pluto Press } & \text { New Hogtown Press } \\ & \\ & \text { Small Press } \\ \text { Three Essays Collective } & \text { Fanele } \\ \text { Mireva Publications } & \text { Irwin } \\ \text { Acorn Press } & \text { Humanities Press } \\ \text { Allen \& Unwin } & \text { Montréal: Méridien } \\ \text { Killick Press } & \text { Dimension Books } \\ \text { Douglas \& McIntyre } & \text { Pinter } \\ \text { Calabash Press } & \text { Mosaic Press } \\ \text { Boreal } & \text { Prestige Publications } \\ \text { Lawrence \& Wishart } & \text { Wall \& Thompson } \\ \text { Westminster/John Nox Press } & \text { Mansell } \\ \text { Goose Lane Editions } & \text { M.G. Hurtig Ltd }\end{array}$




\section{APPENDIX B}

\section{Economics}

1. American Economic Review

2. Econometrica

3. Journal of Political Economy

4. Journal of Economic Theory

5. Quarterly Journal of Economics

6. Journal of Econometrics

7. Econometric Theory

8. Review of Economic Studies

9. Journal of Business and Economic Statistics

10. Journal of Monetary Economics

11. Games and Economic Behavior

12. Journal of Economic Perspectives

13. Review of Economics and Statistics

14. European Economic Review

15. International Economic Review

16. Economic Theory

17. Journal of Human Resources

18. Economic Journal

19. Journal of Public Economics

20. Journal of Economic Literature

Top 3

1. American Economic Review

2. Econometrica

3. Journal of Political Economy

Top Canadian

Canadian Journal of Economics - source: Kalaitzidakis et al. (2003).

Political Science

1. American Political Science Review

2. American Journal of Political Science

3. International Organization 
4. Foreign Affairs

5. Journal of Politics

6. International Security

7. Journal of Conflict Resolution

8. World Politics

9. Journal of European Public Policy

10. International Studies Quarterly

11. Public Choice

12. Journal of Common Market Studies

13. British Journal of Political Science

14. Journal of Peace Research

15. Journal of Law Economics and Organization

16. Comparative Political Studies

17. Journal of Democracy

18. Europe-Asia Studies

19. European Union Politics

20. Political Research Quarterly

Top 3

1. American Political Science Review

2. American Journal of Political Science

3. International Organization

Top Canadian Journal

Canadian Journal of Political Science Source: Hix (2004).

Sociology

1. American Sociological Review

2. American Journal of Sociology

3. Social Forces

4. Social Problems

5. Demography

6. Social Science Research

7. Sociology of Education

8. Social Psychology Quarterly

9. Sociological Quarterly 
10. Criminology

11. Sociological Methods and Research

12. CRC Program and Social Science Reward Structures

13. Journal of Research in Crime and Delinquency

14. Journal of Health and Social Behavior

15. Symbolic Interaction

16. Journal of Criminal Law and Criminology

17. Journal for the Scientific Study of Religion

18. Social Networks

19. Sociological Perspectives

20. Sociological Inquiry

21. Journal of Marriage and the Family

Top 3

1. American Sociological Review

2. American Journal of Sociology

3. Social Forces

\title{
Top 2 Canadian
}

1. Canadian Journal of Sociology

2. Canadian Review of Sociology and Anthropology

Source: South Dakota State University online - $\underline{\text { http://sociology.sdstate.edu/departments/ }}$ journals.pdf - reprint from Footnotes (1990)

\begin{abstract}
Alex Mochnacki is a $\mathrm{PhD}$ student at McGill University. His research interests include the study of social movements, political sociology, cultural industries and policy, and the sociology of culture. Specifically, he is interested in the politics of copyright law. A 2009-2012 SSHRC Scholar, he is currently researching two social movements: the movement of literary authors for international copyright in 19th century America and the contemporary Fair Copyright movement in Canada.zygmunt.mochnacki@ mail.mcgill.ca
\end{abstract}

Neil McLaughlin is an associate professor in sociology at McMaster University, where he teaches sociological theory. His research interests are in the sociology of knowledge and ideas. His most recent publications include "Collaborative Circles and Their Discontents: Revisiting Conflict and Creativity in Frankfurt School Critical Theory," in Sociologica 2/2008; "Global Public Intellectuals, Autonomy and Culture: Reflections Inspired by the Death of Edward Said" in Cultural Autonomy: Frictions and Connections, Petra Rethmann, Imre Szeman, and William D. Coleman, editors. Vancouver: University of British Columbia Press, (in press); and (with Skaidra Trilupaityte) "The International Circulation of Attacks and the Reputational Consequences of Local Context: Scapegoating Soros in Russia, Post-Soviet Lithuania and the United States, 2005-2006" (forth- 
764 C) Canadian Journal of Sociology/Cahiers Canadiens de Sociologie 34(3) 2009

coming Cultural Sociology). nmclaugh@mcmaster.ca 